\title{
半導体発光素子の研究開発動向
}

米津宏雄*

\section{Trend of Research and Development for Semiconductor Light Emitting Devices}

\section{Hiroo Yonezu}

\begin{abstract}
Synopsis
This paper reviews present states and future trends of research and development of semiconductor light emitting devices of LDs and LEDs, including optoelectronic applications. The trends are lower threshold current, higher optical power, shorter wavelength and novel operation in OEICs. Quantum well structures are essential for low current operation required in OEIC. Atomically controlled heteroepitaxy and fine pattern processing are required for realizing the quantum wire and quantum box. Total high technologies of heteroepitaxy and processing lead to high power density operation. Possible materials for short-wavelength-light of blue and green are presented including II-VI compound semiconductors. A large optoelectronic field would appear after realization of combination of compound semiconductors and $\mathrm{Si}$. The basic common technology for these research and development is heteroepitaxy in which growth mechanisms should be studied in atomic level.
\end{abstract}

1. 光エレクトロニクスの概要

半導体レーザの室温連続発振が1970年に達成さ れてから20年強の間に, 光エレクトロニクスとい われる新しい世界が開けた。光通信, 光情報処理 及び光計測はその代表例である。これらはェレク トロニクスだけでは㬰現し得ない卓越した能力を 有するシステム及び機器である（図 1)。そこでの キー・デバイスは半導体レーザ，発光ダイオード 及び受光ダイオードなどの光デハイスである。 光通信は中継間隔を長くとれるために，国内や

1992年 6 月16日受付

・豊橋技術科学大学工学部教授, 工博
欧米諸国の陸上通信網だけでなく，国際海底中継 通信にも実用化され，我々は遅れの少ない国際電 話の恩恵を受けている。高速・大容量化の流れは な続き, $1 \mathrm{~Gb} / \mathrm{s}$ 台から $10 \mathrm{~Gb} / \mathrm{s}$ を超す領域に入ろ うと研究開発は進められている。一方では, ISDN に見られるように家庭への光通信化が進す5とし ている。

光情報処理では，高速のレーザブリンタ，高密 度記録の光ディスクメモリ，バーュードリーダな どの高性能な情報端末機器が情報化社会に大きく 貢献している。また, 超高速・並列演算を目指し た光コンピューティングの基礎研究す進められて いる。さらに，超高輝度発光ダイオード (LED) の開発によって, 各種のディスブレイは近年めざ 


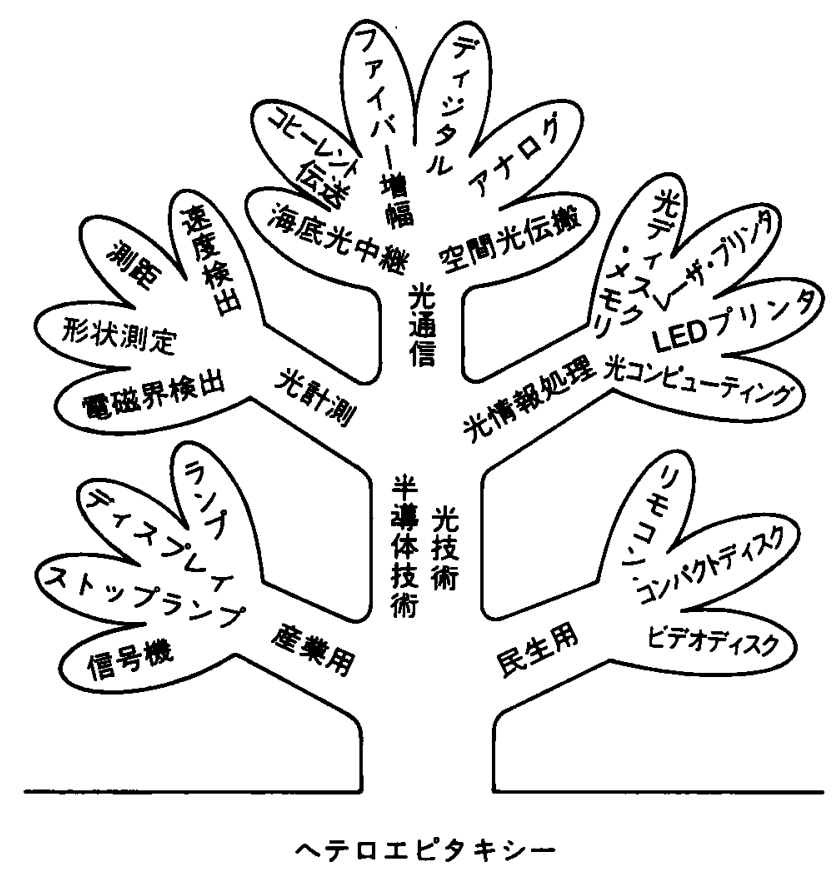

因 1 光エレクトロニクスの構成

ましい発展を続けている。青色の高輝度 LEDが 開発されれぱフルカラーが可能になることからそ の研究開発に長年の期待がかけられている。

民生用では，針式レコードを一新してしまった $\mathrm{CD}$ や ビデオディスクリモコンなどとして光デ ハイスは家庭に広く入り込んでいる。

因1に示されているように，光デバイスをキ 一・デハイスとしたシステム・機器は今後一層広 がをみせると思われる。これらの光デバイスは， 光学的な光技術に負らところる大きいが，エピタ キシー技街に極めて大きく依存している。

鉄と非鉄といら言葉を半票体の世界にあてはめ れば，シリコンと化合物半導体（非シリコン）と いらことになる。シリコンはLSIにその巨大な姿 を見ることができる。しかし，間接逜移型の結晶 材料であるから本質的に発光は難しい。

一方, GaAs, AlGaAs, InP, InGaAsP, GaInP などの化合物半導体の多くは直接题移型の結晶材 料であるために，高い效率で発光が生ずる。これ らの元素を自由に报って，発光波長を制御するだ けでなく，発光素子としてのチッブ構造むエビタ キシー技術で作ってしま5。最近では，原子首レ ベルで結晶の組成や原子の配列を制御する研究が
進んでいる。

以下に，光デハィイスの代表である半導体レーザ と発光がイオードについて，その基礎となるェピ タキシー芰術に触れながら，研究開発状況と今後 の技術動向について概説する。

\section{2. 半刑体レーザ}

\section{1 基本權造とレーザ発振波長}

半寀体レーザは電気的には単なるダイオードで あるために,レーザダイオード (LD: Laser Diode)と乎ばれる。バンドギ+ッブの小さな薄い （約 $1000 \AA ）$ 活性層がハシンドギャップの大きなク ラッド㬝に挟まれ，クラッド周の一方が形，他 方が p形になって、ダイォードを構成している(図 2(a))”。この粠造はダブルニテロ構造といわれ， 高効率の発光を得るための最す基本的な構造であ る。すなわち，順方向バイスス下でn形クラッド 屏から注入された龟子と $\mathrm{p}$ 形クラッド㕣から注入 されたホールが活性層に閉じ込められる。奄流密 度を上げると，活性層の電子とホールの密度は上 がり，誘導放出，すなわち光波の增幅が生ずる。 活性層の屈折率がクラッド居の屈折率上り高いた めに光波も活性層に閉じ込められる。したがって, 


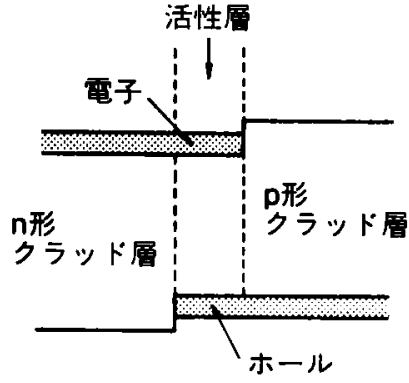

(a)ダブルヘテロ䊔造

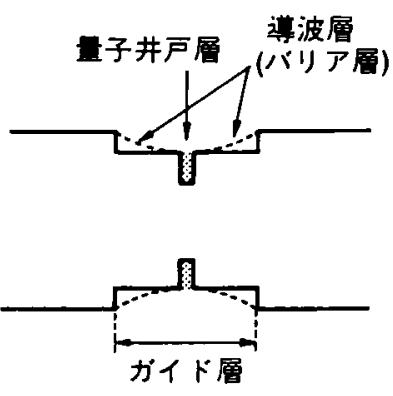

(b)量子井戸構造

図 2 ダプルヘテロ構造と量子井戸構造
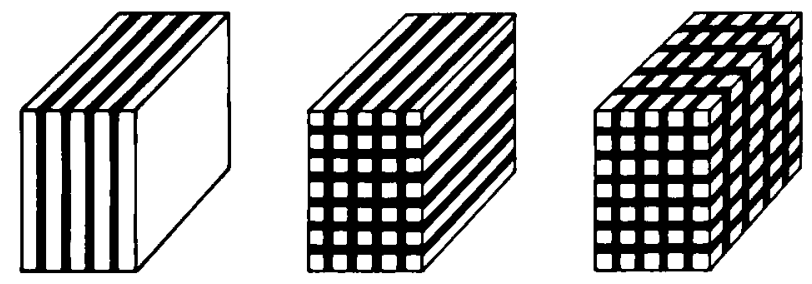

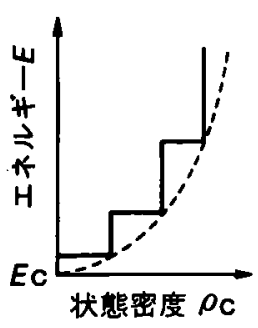

(a) 1次元

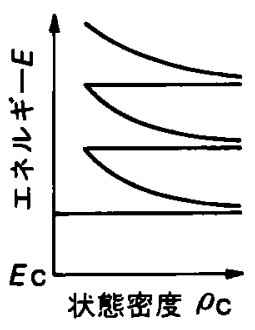

(b) 2次元

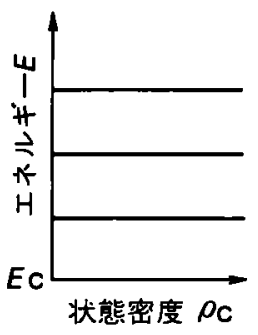

(c) 3次元

图 3 一次元，二次元及び三次元の量子井戸構造（超格子）之電子のエネ ルギー状態密度2)

一対の反射面を構成すれば，誘導放出の利得が共 振器損失に打ち勝つ電流でレーザ発振が生ずる。 レーザ発振に必要な電流密度（しきい電流密度）

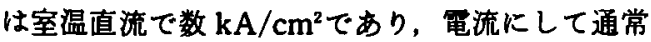
40ー50mAである。

レーザ発振波長 $\lambda_{0}$ はぼ活性層のバンドギャ ップ $E \mathrm{~g}$ で決まる $\left(\lambda_{0}[\mu \mathrm{m}]=1.24 / E \mathrm{~g}[\mathrm{eV}]\right) 。$ すなわち，レーザ発振波長は活性層の結晶材料で 决まる。表 1 に主な結晶材料とレーザ発振波長が 示されている゙。黒く塗りつぶされたところがこ
れまでに室温連続発振が達成された波長である。

\section{2 低しきい龟流化}

しきい電流密度を下げるために活性層を $100 \AA$ 弱に薄くした構造は量子井戸構造といわれる（図 2(b)，(図 3(a)) 2)。この薄い五子井戸居では光を 閉じ込めることができないため，その外側に光波 閉じ込め用の導波層を設ける。これによって，し きい龟流密度は約 1 析下が，しきい電流 $I_{\mathrm{th}}$ は数 $\mathrm{mA}$ に下がる。これまでにlmAを切るしきい電流 が報告されている3)。 


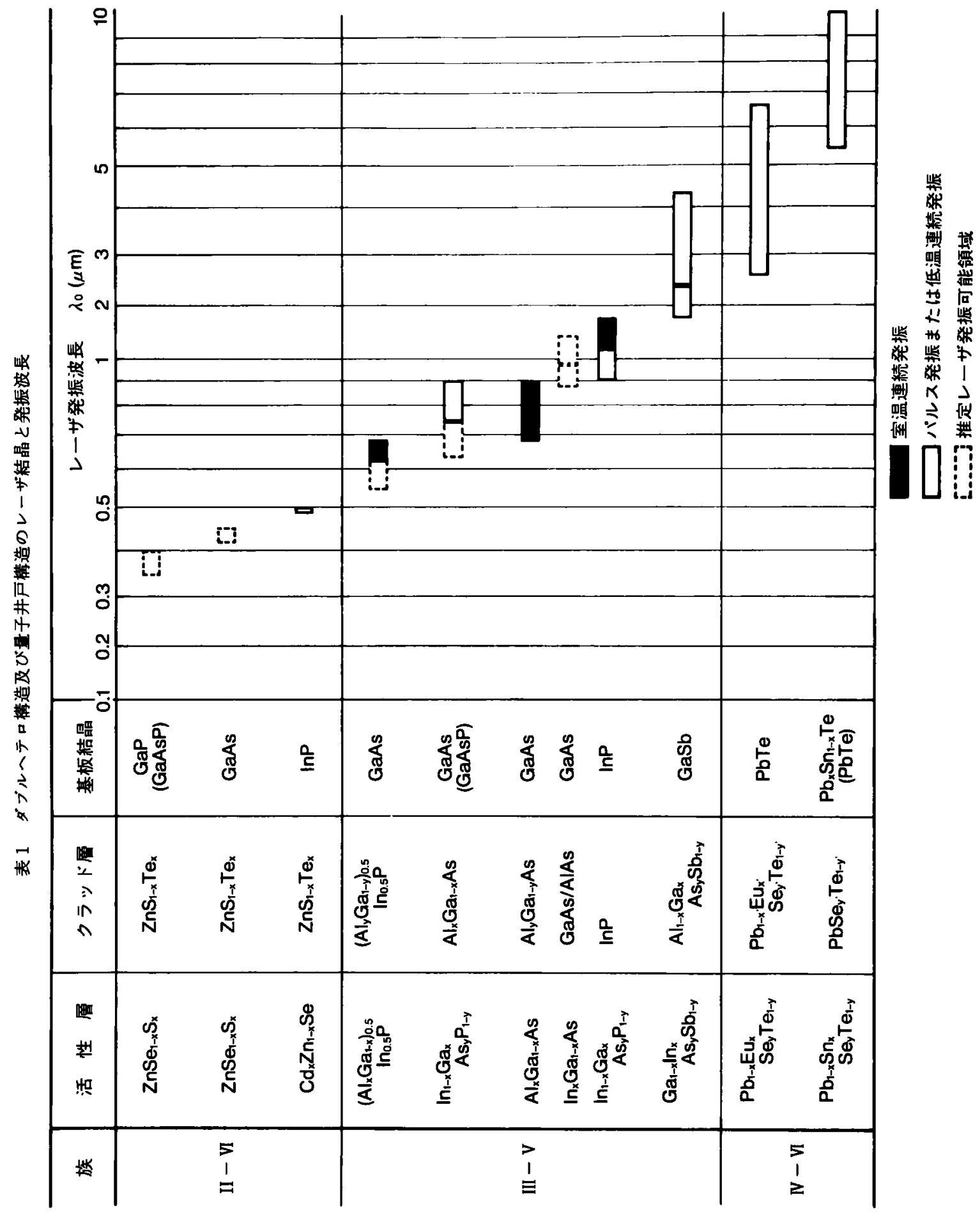


厚さ $(x$ 方向)を薄くするたけけでなく，y 方向に も薄くした量子細線（图3(b)）では，さらにしき い電流密度が下がことが理論的に予測されてい るい。電子ビーム露光などの敞細加工技術に加之 て, 各種のエピタキシャル成長技術が世界的に試 みられている。理論值上り大きいが $I_{\mathrm{th}}=3 \mathrm{~mA} か$ 報告されている5”。

さらに，z方向も薄くした量子箱（图 3(c)）で は，さらにしきい電流が下がることが理論的に予 測されている。やはり，微細加工技術とエピタキ シャル技術を組み合わせてこの構造の実現が試み られている。しかし，製作技術が難しいため、レ 一ザとしての実稌結果はまだ報告されていない。

このよ5に, ダブルヘテロ構造から量子井戸構 造にし，さらに量子化の次元を上げていくと，し きい電流密度たけけでなく，変調速度やスベクトル 線幅などのレーザ特性が優れることが明らかにさ れている゙。図 2(b)の量子井戸レーザは既に一 部実用化されており，光通信や光情報処理あるい は光計測に必要不可欠である。

さらに，しきい電流を下げるために，量子箱の $x y z$ の全方向に高反射率の共振器を構成寸る構 造が提案されている6)。自然放出光が特定のモー ドに制御されるために，究極的には無しきい値レ ーザとなる。

\section{3 高出力化}

光出力密度を高くすることにより，光磁気ディ スクの書き込及時間を短くしたり、レーザブリン タの印字速度を上げたり，光通信の中継間隔を伸 ばすなどの機能の向上が得られる。

$0.7 \mu \mathrm{m}$ 帯波長の $\mathrm{AlGaAs}$ レーザや0.6 $\mu \mathrm{m}$ 帯波 長の GaInP レーザでは，光出力密度を高くしてい くと光学損稘が発生し，一瞬にして破壊する。こ れは反射面近傍の活性層が強いレーザ光を吸収し て発熱し、溶融してしま5現象である。このため, 量子井戸構造にして活性層童薄くし, 光出力密度 を下げると光学損傷が発生する臨界光出力が大き くなる。さらに, 主光出力の取り出し面の反射率 を下げて反対側の反射面の反射率を上げることに よって，主光出力を大きくできる。

また，反射面近傍が吸収体になるのは，これら の結晶材料の表面物性に基ついた現象であるた め, 根本的に改善する訊みも行われている。そこ では，反射面近傍をバンドギャッブの大きな結晶
材料で構成してレーザ光の吸収を防ぐ。この種の レーザ構造はウィンドゥ構造と呼ばれる゙。これ らの改良によって，AlGaAsレーザでは基本横モ 一ト発振で CW 光出力 $100 \sim 200 \mathrm{~mW}$ の長期安定 動作が近年報告されている゙。

光学損傷が同様に発生する GaInP レーザでは, 伝導帯のへテロ障壁の高さが低いために, 活性層 の電子がオーハーーフローしやすく，高温での高出 力動作が AlGaAs レーザに比へてて難しい。

一方, 光通信に主に用いられる InGaAsP レー ザでは明白な光学損偒は報告されていない。これ はこの結晶材料の表面再結合速度が遅いためであ る。したがって、ウィンドウ構造のような特殊な 工夫なしに基本横モード発振で $\mathrm{CW}$ 光出力 $100 \sim 200 \mathrm{~mW}$ の長期安定動作が得られる。

なお゙, 発振領域幅を厇げたレーザでは, 横モー ドは多モードになってレーザ光の品質は悪くなる が，発提領域幅が広がった分だけ光出力を大きく することができる。この場合，量子井戸の厚さに 対して高い均一度が求められる。この種のレーザ では 1 チップで 1 3W の CW 光出力が得られて おり, 固体 YAGレーザの励起光源などに用いら れる。

このよらな改良努力が皘み重ねられて, 光出力 は着実に高くなっていくと考えられる。ここでも， 薄い均一な量子井戸層を得るためのエピタキシー 技術が必須である。

\section{4 短波長化}

一般に，活性層に転位などの非発光性結晶欠陷 を導入しないために，活性層とつラッド層，また は量子井戸層と導波層の格子定数は基板之一致 （格子整合）している必要がある。このため，図

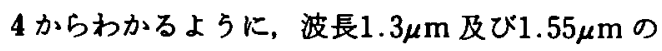
光通信用には InP 基板上に InGaAsP 活性層之 InP クラッド㬝がェビタキシャル成長される゙。波 長 $0.78 \mu \mathrm{m}$ の CD 用や光磁気ディスク用には $\mathrm{GaAs}$ 基板上に AlGaAs の活性層とクラッド層が エピタキシャル成長される。また，波長 $0.65 \mu \mathrm{m}$ の ベーコードリーダや各種の可視光用途には GaAs 基板上に GaInP 活性層と AlGaInP クラッド層が エピタキシャル成長される。

ところで，緑色，青色，紫外光といったより短 波長のレーザでは，より小さなスポットによる高 密度の光ディスクメモリや化学反応への応用など 


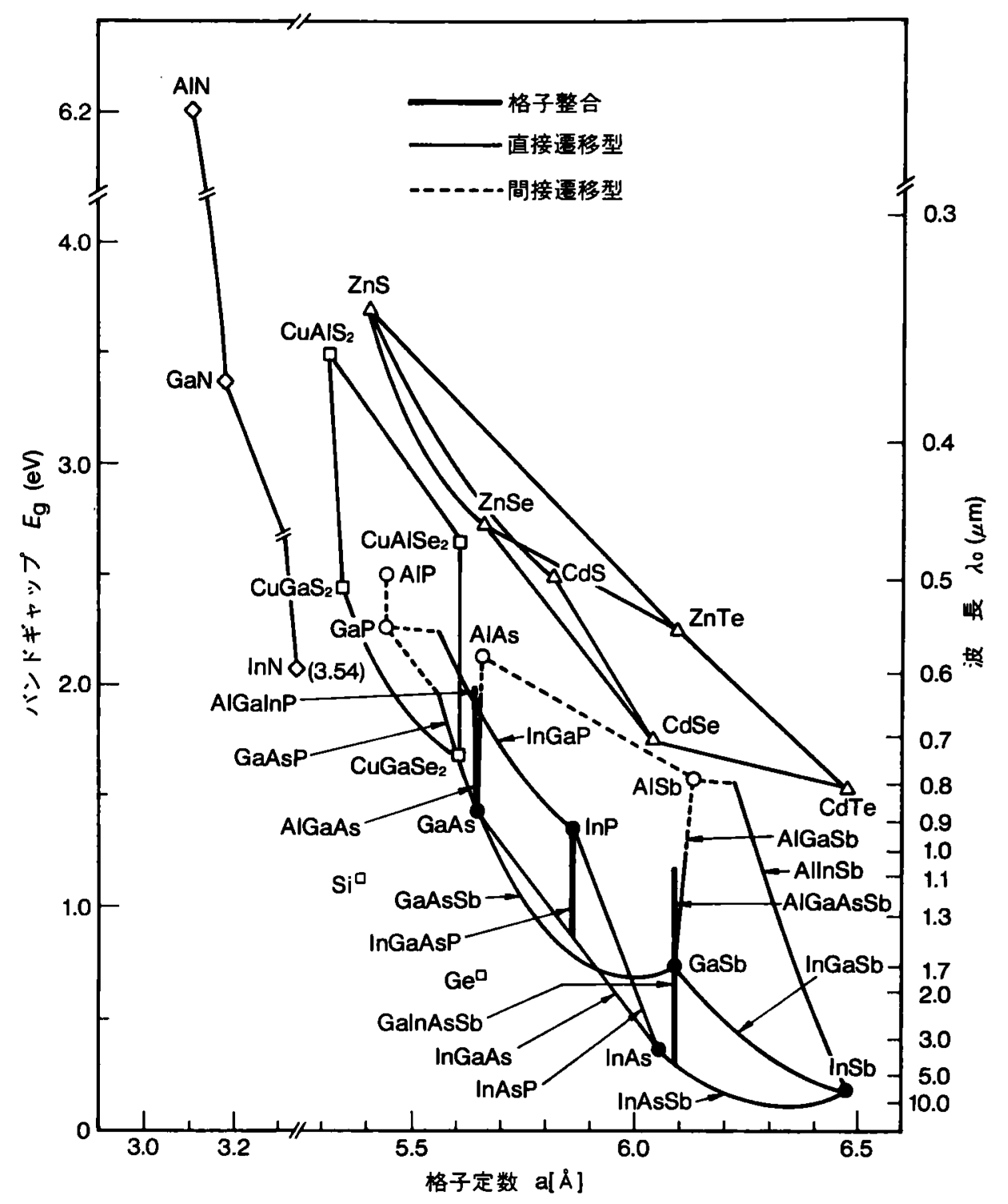

図 4 半導体結晶の格子定数とペンドギャッブ1

が可能となり，その用途は広い。しかし，図4 か らわかるように，これらの波長に対しては該当す る閃覀鉛鉱型のIII-V族化合物半導体はない。青 色と緑色の候補としては，ZnCdSe 系やZnSeTe 系の II - VI族化合物半導体と GaInN 系のウルッ 鉱型のIII-V族化合物半導体が挙げられる。これ らの結晶材料に対しては，格子整合する基板が存 在しない。このため，II－VI族化合物半導体のエ ピタキシャル成長にはIII-V族化合物半導体基板
が用いられることが多い。

ところで，量子井戸のよらな薄さになると，0.1 \%以下の格子定数の違い（格子不整合）があって る下地の結晶に横方向の格子定数を合わせ，綎方 向に昰んでェピタキシャル成長する(图 5(a))。こ の成長層を厚くしていくと，雪が大きくなってつ いにはミスフィット転位が発生して格子が緩和す る(図 5(b))。この格子緩和が始まるエピタキシャ ル㟄の厚さは臨界膜厚といわれる。すなわち、最 


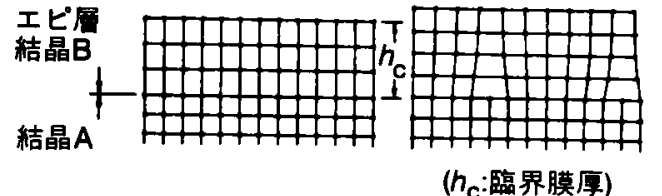

(a) 楥和前

(b) 緩和嵝

近の原子層レベルで制御されたエピタキシー技術 では，臨界膜厚以下で量子井戸層の厚さを制御で きるため，結晶材料の選択に少し幅が広がってき た。

この技術を用いて $\mathrm{ZnCdSe}$ を量子井戸層とし， $\mathrm{ZnSe}$ を導波層とした量子井戸レーザで77 Kの青

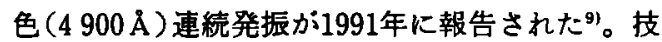
術的改良によって室温連続発振が目指されてい る。

\section{5 光電子集穔回路}

微小奄流動作は, LSI 駆動が可能になるために, 光回路之電子回路を一体化した光電子集積回路 (OEIC : Optoelectronic Integrated Circuit) に は必須である。

チップ上面からレーザ光が放出される面発光レ ーザにはチッブ内での配置を自由に行えるといら 利点がある ${ }^{10)}$ 。图 6 では, InGaAs 量子井戸層の上 下に高い反射率を得るための分布反射器（DBR： Distributed Bragg Reflector) が形成されてい る11)。そこでは, AlAs/GaAsの屈折率がわずかに

異なる層が半波長の厚さで繰り返し多層エピタキ シャル成長されている。薄い量子井戸のために上 下方向の利得は小さいが，DBRによって98\%の高 い反射率が得られるために, $1 \mathrm{~mA}$ を切るしきい電 流が得られる。

ところで，この例では InGaAs 量子井戸層の格 子定数は $\mathrm{GaAs} / \mathrm{AlAs}$ パリフ層とわずかに異なる ため，量子井戸層は歪を受けている。面発光レー ザに限らず，この上らな昰を受けた貫子井戸では 価電子帯のバンド構造が变わるために，しきい電 流密度が下がり, 高い变調速度が期待される。こ のため,この種のレーザは歪量子井戸レーザと呼 ばれる。

このよらな微小電流動作をする面発光レーザを 1 チップ内に二次元に多数配列すると，空間光並 列光源や光配線ができる。これに，1チッブ内に 二次元配列した量子井戸構造の受動演算素子

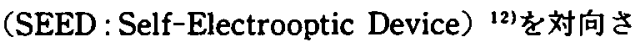
せて，超高速・並列ディジタル演算を行う試みが されている13)。

1 チップ内に電子回路とレーザを構成できれ ば，単に小形化できるたけでなく，配線によるイ ンダクタンスが减るなどのために高速動作が容易 になる。同じ化合物半導体結晶内に LD L LED あるいは受光素子と，FETゃ HBTを作った OEIC は光通信の送信器あるいは受信器としてす

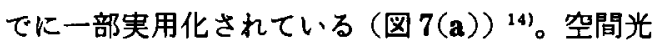
並列配線を用いた光電子ニューロコンピューティ ンク用の OEICでは優れた機能が期待される（図

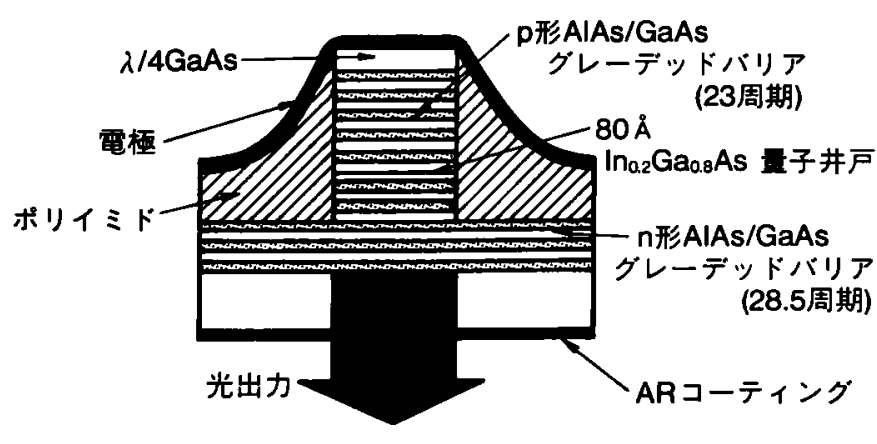

(a)チップ断面粠造

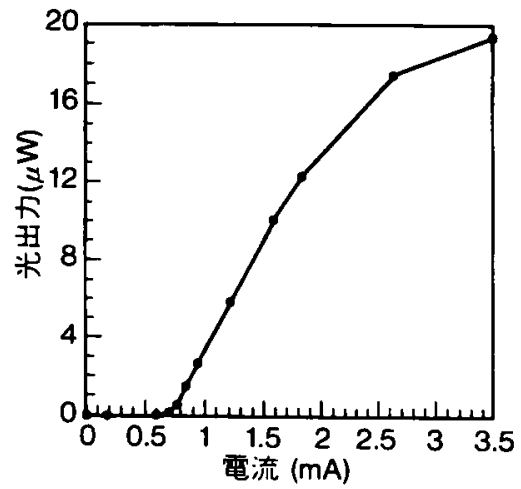

(b) 電流一光出力特性

図 6 InGaAs 歪量子井戸面発光レーザ'11 


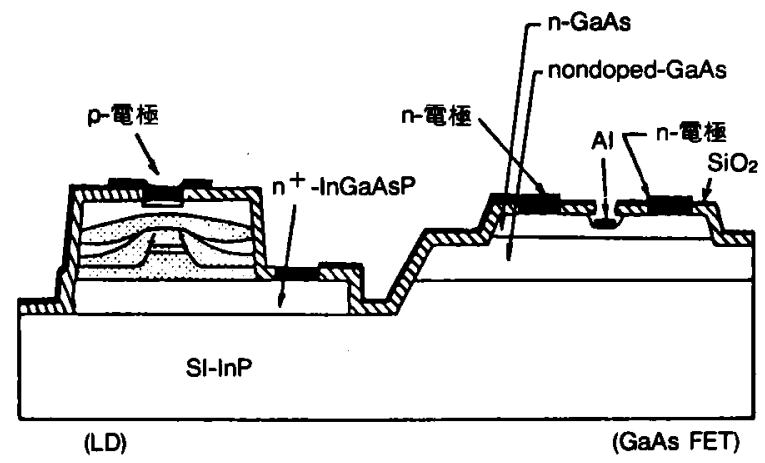

(a) チップ断面㩐造

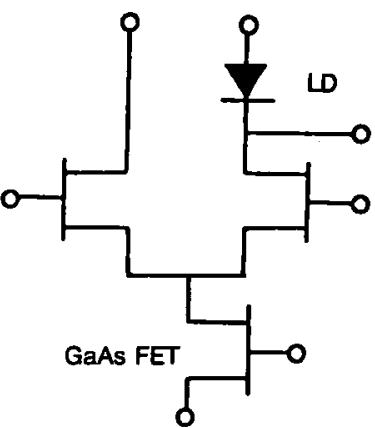

(ii) 回 路

(i) 光送信用OEIC $(C D+F E T)^{14)}$

(光黾子ニューロデパイス)

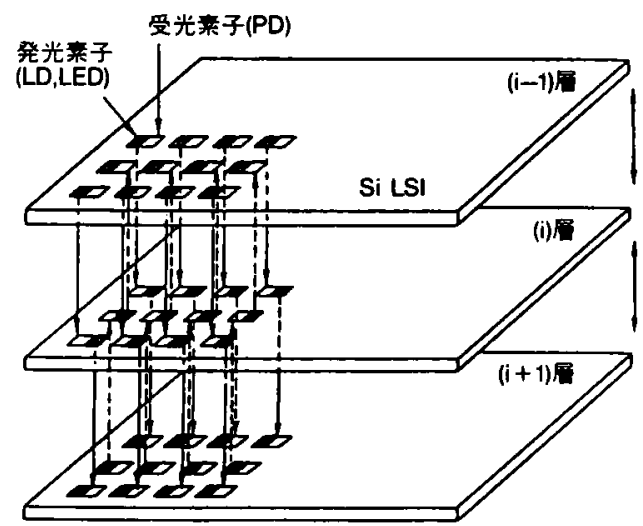

(b) 多層ニューラルネットワーク用OEICの構成概念図 ${ }^{15)}$

図 7 OEIC

$7(b))^{15)}$ 。

本来の光子と電子の機能的特徵を組み合わせた $\eta$ ，大規模な電子回路と光回路を組み合わす場合 には，電子回路の設計・製造能力に優れるシリコ ンとの組み合わせが必要不可久である。したがっ て，GaAsなどの化合物半導体とシリコンとのへ テロエピタキシーが必要である。格子定数を初め, 諸々の物性が異なるために現時点ではデバイスレ ベルの良質なエピタキシャル層は得られていな い。しかし，その必要度の高さから，新たなブレ ークスルーを目指して基礎研究が世界で進められ ている。

\section{3. 発光ダイオード}

\section{1 功作原理と発光波長}

発光ダイオードは，伝導帯に励起された電子が 価電子帯のホールと再結合する祭にエネルギーが
失われるが，その際光子が放出される現象を利用 している。励起方法は半導体レーザと同様に pn 接合に順方向奄流を流す注入励起である。超高輝 度 LED では，活性層での電子一ホール対密度を 上げるために，半導体レーザと同様にダブルヘテ 口構造が用いられる。

発光波長はほぼハンンドギャップに相当する光子 エネルギーの波長である。したがって，伀迸带と 価電子带のハンンド間遷移では, 図4からわかるよ 丂に, $\mathrm{Al}_{x} \mathrm{Ga}_{1-x} \mathrm{As}$ の Al 組成比 $x$ を変えて $0.6 \mu \mathrm{m}$ 帯波長の赤色か $50.8 \mu \mathrm{m}$ 帯波長の近赤外までカ ハーできる。しかし，閃严鉛鉱型のIII－V䓡化合 物半導体では最短波長はAlGaInP の黄色程度で ある。光通信には, $\mathrm{In}_{1-x} \mathrm{Ga}_{x} \mathrm{As}_{y} \mathrm{P}_{1-y}$ の $\mathrm{Ga}$ 組成比 $x$ と As 組成比 $y$ を変えて $1.3 \mu \mathrm{m}$ 及び $1.55 \mu \mathrm{m}$ の 波長が得られる。このよらな直接遷移型のハン・ド 間要移を用いる LED ではダブルへテロ構造によ 
って極めて高い唛度の発光が得られる。このため， 直接透移型のII－VI族化合物半学体による青色中 粶色の高輝度 LED が期待されている。前述の青 色レーザの ZnCdSe や ZnSeTe 系が候補として あげられる。

一方，不純物を導入すると固有のレベルがハン ドギャップの中にできる(图8(a))。リモコン用の 赤外 LED はその典型例で，GaAsにSi を多量ド ーブして，Siが作るレベルからの発光を利用す る。また， Znをドーブした $\mathrm{GaN}$ から青色発光が 得られる。

間接套移型結晶では，等電子トラッブを介した 発光や不純物に束繧された励起子の崩壊による発 光を利用する。前者の典型例はNをドーブした GaP であり，緑色発光の LED として広く用いら れている。後者の典型例は $\mathrm{Zn}-0$ をドープした GaP で，赤色発光の LED として用いられる(図 8
(b)，(c))。SiCによる青色 LED るその例である。 これらの結果が表 2 にまとめられている ${ }^{16) 。}$

\section{2 高糢度化}

発光ダイオードの光出カについては，活性風の 発光効率 (内部量子効率) 以外にチップの外へ光 を取り出す，光取り出し効率が重要な因子にな る”。直接题移型のダブルヘテロ構造を有する LEDは，内部量子効率が高いだけでなく，クラッ ド層での光吸収がほとんどないために活性居から の光をチップ外に効率よく取り出し易い。

一般に，チッブ上面（表面）から光を放出する 場合, 下面 (襄面) 人向か5発光は散乱・吸収さ れて失われる。したがって，裏面の反射率を $100 \%$ 近くに上げると，表面からの光出力は 2 倍に上か る。これには兾面を鏡面研磨してその上に Auな どの金属蒸着膜をオーミック電極と兼ねて付ける 方法 ${ }^{17}$ と，面発光レーザに見られた多層半導体薄

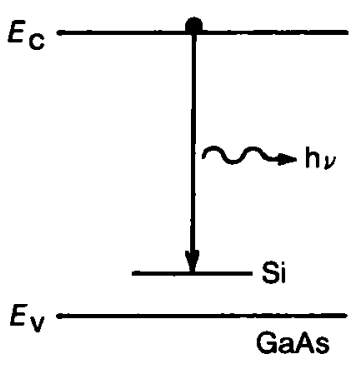

(a) 不純物レペル

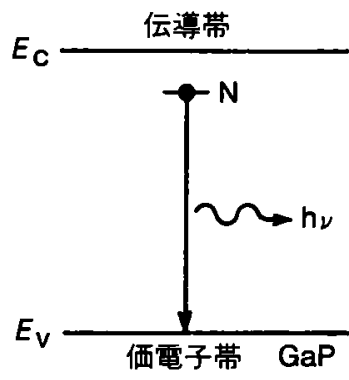

(b) 等電子トラップ

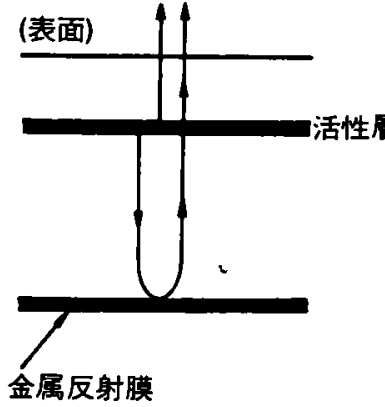

(a) 自面金属反射膜 ${ }^{17)}$

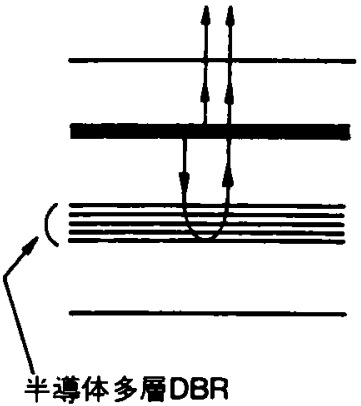

(b) 素面半道体多層DBR ${ }^{18}$

因 9 光取り出し効率の向上策

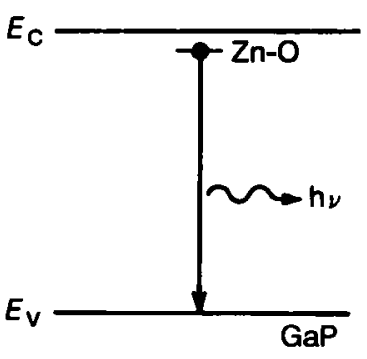

(c) 束縛励起子

図 8 不純物を介した発光 
表 2 発光ダイオード用結晶と発光波長 ${ }^{(6)}$

\begin{tabular}{|c|c|c|c|c|c|c|c|c|}
\hline \multirow{2}{*}{\multicolumn{2}{|c|}{ 波 長 域 }} & \multicolumn{2}{|c|}{ 結 晶 材 料 } & \multicolumn{2}{|l|}{ 発 } & \multicolumn{2}{|c|}{ 結 晶 成 長 } & \multirow{2}{*}{ 主 用 途 } \\
\hline & & 発光首 (活性層) & 基板 & $\begin{array}{c}\text { 中心波長 } \\
\text { (nm) }\end{array}$ & 㓳移型 & 方 法 & 構 造 & \\
\hline 赤 & $1 \mu \mathrm{m}$ 帯 & $\begin{array}{l}\mathrm{In}_{0.85} \mathrm{Ga}_{0.95} \mathrm{As}_{0.79} \mathrm{P}_{0.21} \\
\mathrm{In}_{0.78} \mathrm{Ga}_{0.24} \mathrm{As}_{0.55} \mathrm{P}_{0.45} \\
\mathrm{In}_{\mathbf{0}_{0.82}} \mathrm{Ga}_{0.18} \mathrm{As}_{0.40} \mathrm{P}_{0.60}\end{array}$ & $\operatorname{InP}$ & $\begin{array}{l}1550 \\
1300 \\
1150\end{array}$ & 直接 & $\begin{array}{l}\text { LPE } \\
\text { VPE }\end{array}$ & DH & 光通信 \\
\hline 外 & $0.9 \mu \mathrm{m}$ 帯 & $\mathrm{GaAs}(\mathrm{Si})$ & $\mathrm{GaAs}$ & 940 & 直接 & LPE & HM & リモコン \\
\hline 光 & $0.8 \mu \mathrm{m}$ 帯 & $\begin{array}{l}\mathrm{GaAs} \\
\mathrm{Al}_{0.03} \mathrm{Ga}_{0.97} \mathrm{As} \\
\mathrm{Al}_{0.15} \mathrm{Ga}_{0.85} \mathrm{As}\end{array}$ & GaAs & $\begin{array}{l}870 \\
850 \\
780\end{array}$ & 直接 & $\begin{array}{c}\text { LPE } \\
\text { MOVPE }\end{array}$ & $\mathrm{DH}$ & 光通信 \\
\hline 可 & 赤 & $\begin{array}{l}\mathrm{GaP}(\mathrm{Zn}-\mathrm{O}) \\
\mathrm{Al}_{0.95} \mathrm{Ga}_{0.65} \mathrm{As} \\
\mathrm{InGaP}\end{array}$ & $\begin{array}{l}\text { GaP } \\
\text { GaAs } \\
\text { GaAs }\end{array}$ & $\begin{array}{c}700 \\
660 \\
630 \sim 650\end{array}$ & $\begin{array}{l}\text { 間接 } \\
\text { 直接 } \\
\text { 直接 }\end{array}$ & $\begin{array}{c}\text { LPE } \\
\text { LPE } \\
\text { MOVPE }\end{array}$ & $\begin{array}{c}\mathrm{HM} \\
\mathrm{DH}, \mathrm{SH} \\
\mathrm{DH}\end{array}$ & $\begin{array}{l}\text { ランプ, 表示 } \\
\text { ランプ, 光通信 } \\
\text { ランプ, 表示 }\end{array}$ \\
\hline 視 & $\begin{array}{l}\text { 橙 } \\
1 \\
\text { 黄 }\end{array}$ & $\begin{array}{l}\mathrm{GaAs}_{0.25} \mathrm{P}_{0.75}(\mathrm{~N}) \\
\mathrm{GaAs}_{0.15} \mathrm{P}_{0.85}(\mathrm{~N}) \\
\mathrm{Al} \operatorname{InGaP}\end{array}$ & GaP & $\begin{array}{c}610 \\
590 \\
570 \sim 610\end{array}$ & $\begin{array}{l}\text { 間接 } \\
\text { 間接 } \\
\text { 直接 }\end{array}$ & $\begin{array}{c}\text { VPE } \\
\text { VPE } \\
\text { MOVPE }\end{array}$ & $\begin{array}{l}\mathrm{HM} \\
\mathrm{HM} \\
\mathrm{DH}\end{array}$ & ランブ,表示 \\
\hline 光 & 緑 & $\begin{array}{l}\mathrm{GaP}(\mathrm{N}) \\
\mathrm{GaP}\end{array}$ & $\mathrm{GaP}$ & $\begin{array}{l}565 \\
555\end{array}$ & 間接 & LPE & HM & ランブ, 表示 \\
\hline & 青 & $\begin{array}{l}\mathrm{GaN} \\
\mathrm{SiC}\end{array}$ & $\begin{array}{c}\mathrm{Al}_{2} \mathrm{O}_{3} \\
\mathrm{SiC}\end{array}$ & $\begin{array}{l}490 \\
480\end{array}$ & $\begin{array}{l}\text { 直接 } \\
\text { 間接 }\end{array}$ & $\begin{array}{l}\text { VPE } \\
\text { LPE }\end{array}$ & $\begin{array}{l}\text { MIS } \\
\text { MIS }\end{array}$ & ランプ \\
\hline
\end{tabular}

$\mathrm{DH}:$ ダブルヘテロ構造, SH : シングルヘテロ構造, HM : ホモ接合, MIS : MIS 檴造

LPE : 液相成長, VPE : 気相成長, MOVPE : 有機金属気相成長法

膜によるDBRをエピタキシャル成長時に作る方 法 ${ }^{18)}$ とがある（図 9(a)，(b))。後者は透過波長域 や反射率を設計できることから，MOVPEゃ MBEで実現できる新しい基碟技術である。

一方，光取り出し面（表面）の空気に対する全 反射角は, AlGaAs の場合的16度と小さい。このた め, 球面加工のような全反射角対策は光取り出し 効率の向上に極めて有効である。(図 9(c)） 19。

超高輝度 LED は，半導体レーザが可能な直接 㟟移型結晶のダブルヘテロ構造に，光取り出し奻 率を上げるための各種の工夫が施されて今日に至 っている。したがって, 超高輝度 LED の研究開発 は半導体レーザのそれと結晶材料面では不可分の 関係にある。

\section{3 高 機 能 化}

$1 \mathrm{~Gb} / \mathrm{s}$ を超す高速光通信用の InGaAs PLED, 高光出力の空中伝般光通信・計測用の AlGaAs LED, さらにスペクトル幅が極めて広い光フフイ
ヘ・シシャィ用の LEDなどが，LED単体の性能 を上げた例としてあげられる。

これに対して，ブリンタ用の LEDの例では，1 $\mathrm{cm}$ 前後の長いハーー状のチッブに200 300 $\mu \mathrm{m}$ ビ ッチで多数の LED が配列される。そこでは, チッ ブ内, チップ間の各 LEDの光出力の均一化が強 く要求される。このため, プロセスの均質化はる ちろんであるが，エビタキシャル層の均質化が最 む重要になる。また，LED ブリンタや光 LAN の 例を見ても，LEDの駆動回路はSi ICによる。こ こでも, 化合物半導体と Si の一体化エピタキシー 技術は重要な将来技術である。

\section{4. 今後の課题と展望}

半導体レーザと発光ダイオードのいずれむ，青 色，緑色，さらに紫外光源といった，短波長化の ための結晶材料の研究は不可避である。フルカラ 一・ディスプレイを初めとして実現したあかつき 
の産業的意義は極めて大きい。新結晶材料の研究 には，MBEゃMOVPEを用いた原子レべルのへ テロエピタキシャル成長機粠の基碟研究が重要で ある。

一方，発光素子の高機能化といら観点からは， 光通信用の OEIC は実用的見地から着実に進展し ていくであろ5。量子細線や量子箱，あるいは無 しきい値レーザなどの微小電流動作は新しい光情 報処理の分野を切り拓く鍵として期待されてい る。これと併せて光の放射角を自在に制御するな どの光制御技術もチップ内に組み込む必要があ る。これらはいずれる細加工技術の必要性を示 している。

さらに広い光電子分野を切り拓く基盤技術とし て，化合物半導体と Si の一体化といら課題があ る。そこで得られる基整的な結果はへテロェビタ キシー全般にかかわる重要な物理的機構を意味し ており，新たな応用への基盤になると考えられる。 これらの研究開発をとおして，真に電子技術と 光技術が融合した光ェレクトロニクスの世界が今 後開かれていくるのと思われる。

\section{（文献）}

1) 米津: 光通信素子工学一発光・受光素子一 (1984) [工学図書]

2）日本物理学会編: 半導体超格子の物理と応用 （1984）[培風館]

3) T.R.Chen, B.Zhao, Y.H.Zhuang and A. Yariv : Appl. Phys. Lett., 60 (1992), 1782

4) 浅田: 応用物理, 57 (1988), 702

5) S.Simhony, E.Kapon, E.Colas, R.Bhat, N.G. Stoffel and D.M.Hwang: IEEE Photon. Lett., 2 (1990), 305

6）山本，上田：電子情報通信学会誌，72 (1989), 1014
7) H.Yonezu, M.Ueno, T.Kamejima and I. Hayashi : IEEE J. Quantum Electron., QE15 (1979), 775

8) E.Latta, A.Moser, A.Oosenbrug, M. Gasser and Th.Forster: 12th IEEE Int. Semicon. Laser Conf., Conf. Digest, Q-4 (1990),276

9) M.A.Haase, J.Qiu, J.M.Depuydt and H. Cheng: Appl. Phys. Lett., 59 (1991), 1272

10) F.Koyama, S.Kinoshita and K.Iga : Appl. Phys. Lett., 55 (1989), 221

11) R.S.Geels and L.A.Coldren : 12th IEEE Int. Semicon. Laser Conf., Conf. Digest. B-1 (1990), 16

12) D.A.B.Miller, D.S.Chemla, T.C.Damen, T. H.Wood, C.A.Burrus, Jr., A.C.Gossard and W.Wiegmann: IEEE J.Quantum Electron., QE-21(1985), 1462

13) A.Huang : 1990 Int. Topical Meeting on Optical Computing, Conf. Record, 10F2 (1990), 259

14）鈴木, 伊東, 井元, 寺門, 笠原, 麻埜, 崎, 清水, 藤田：信学技報, OQE87-184 (1988), 59

15）米津：電子情報通信学会誌, 75 (1992), 350

16）(財)光産業技術振興協会監䇙: 光部品-製品活 用事典(1985)

17) S.Yamakoshi, M.Abe, O.Wada, S.Komiya and T.Sakurai:IEEE J.Quantum Electron., QE-17(1981), 167

18) T.Kato, H.Susawa, M.Hirotani, T.Saka, Y. Ohashi, E.Shichi and S.Shibata: J. Cryst. Growth. 107 (1991), 832

19) K.Kurata, Y.Ono, K.Ito, M.Mori and W. Susaki:IEEE Trans. Electron Devices, ED-28(1981), 374 